\title{
The Performance of Employees Work Discipline Pt. Atri Distribution Pare-Pare
}

\author{
Sri Andayaningsih \\ Department of Management, Faculty of Economics and Business, University of Muhammadiyah Makassar.
}

\begin{abstract}
This study aims to determine the effect of labor discipline on the performance of employees at PT. Atri Distribution Pare-Pare. This study uses quantitative and qualitative data as well as descriptive of primary and secondary data sources. The analytical method used was obtained that affect the performance of the employee discipline employees who value t count $>$ t-table (3.9>1.785). Discipline employee reached $81.73 \%$ or included excellent. Similarly, the performance of employees at PT. Atri Distribution Pare-Pare reached $82.8 \%$ and is at a good rating. Analysis of statistical studies have shown that the discipline with the performance of employees have a level of relationship is (concrete) on the coefficient of determination $r 2=0.3630$, which means that the discipline capable of affecting the performance of $36.30 \%$ and the remaining $63.70 \%$ influenced by other variables. Thus the hypothesis proposed by the author accepted.
\end{abstract}

Keywords: Discipline, work, performance, and Employees

\section{Introduction}

In everyday life a person will not separate from the environment. A person's personality will be formed also by the environment and that these personalities succumb to the positive attitude and behavior that must be supported by recognized norms of truth and obeyed as a guideline for action and take a decision. The role of discipline will be crucial to achieving the desired goals of the organization are included in a company, the company mainly engaged in the field of consumer good distributor as in PT. Atri Distribution Pare-pare, with regard to improving the discipline of employees to improve their performance. The high work discipline is in accordance with the authority and responsibilities of each in order to realize the objectives of the organization.

Discipline factors have a very important role in improving an employee's performance as discipline effective; provide guidance to the efforts of all employees in achieving organizational goals. An effective discipline required and must be applied a leader to be able to improve the performance of all employees in achieving organizational goals as an institution of public servants.

Mangkunagara (2009: 2) argues that "human resource management is a planning, organizing, implementation, and oversight of procurement, development. Service providers, integration, maintenance and the division of labor in order are to achieve the goal. "

Human resources according to Hasibuan (2002: 223) "as an art and a science to acquire, promote and utilize the labor force, so that organizational goals can be realized as efficiently once the excitement in the work of the workers." Further Hasibuan (2002: 241) provide understanding of human resource management as an "integrated capabilities and intellect and physical power of the individual."Mondy (2008: 4) said "Human resource management is the use of a number of individuals to achieve organizational goals".

Dessler (2003: 2) "Human resource management is the policy and ways practiced and relates to human empowerment or aspects of a human resources management positions including recruitment, selection, training, awards, and judgments." Sutrisno (2010: 5) "management of human resources is the utilization, development, assessment, provision of fringe benefits, and management of individuals, members of organizations or groups of workers".

After seeing the above description, it means that human resource management is the management which has the function to handle a wide range of human problems in an organization such as planning, organizing, directing and labor inspection.

Discipline is something that is very important in order to create qualified employees to perform the tasks assigned to him for the achievement of organizational goals. Discipline will be realized with an attitude that reflects adherence to a rule. Achieving discipline in a scope or good behavior in accordance with the rules or norms, ithas been outlined and do exist in the organization.

According Rival (2011: 825): "Discipline of work is a tool used to communicate with the leaders of the workers so that they are willing to change a behavior as well as an effort to raise awareness and the willingness of a person to obey all laws and social norms prevailing in the organizational environment."

Labor discipline is the awareness and the willingness of a person to obey all company rules and norms of social, applicable. With good discipline on employees, the higher the performance to be achieved. Generally, management actions to enforce discipline within an organization / agency composed of two types, namely: 
discipline preventive. Preventive Discipline is an attempt to move the employees to follow and adhere to the guidelines, the rules that have been outlined by the company. By way of prevention, the employee or the employee can maintain itself against the regulations of the company.

\section{Corrective discipline}

Corrective Discipline is an effort to move employees in stating a rule and move to remain in compliance with the regulations in accordance with the guidelines in force at the company. In the corrective discipline employees who violate the discipline needs to be given sanctions under the applicable laws and provide lessons for noncompliance. So, leaders need to work closely with all parts of the system to develop discipline. If the system is a good organization, it is expected that it will be easier to enforce labor discipline (Mangkunagara, 2004: 129).

Labor discipline is an attitude and behavior that shows the loyalty and obedience of a person or group of persons against the rules set by the agency or organization. The success of an organization in achieving discipline employees affected by several factors, namely: Working hourspermission employees Worker's attendance So, if all the factors of discipline employees performing well, then the organization or company can create conditions so that the function of discipline both organizations can work well too.

Performance comes from understanding performance. There also give understanding performance as a result of work or work performance. However, actual performance has a broader meaning, not the work, but how the job is in progress. Sinambela, et all (2012: 5) "Performances of employee is defined as the ability of employees to perform their certain skill".

According to Miner in Sutrisno (2010: 170) "is how one's performance is expected to function and behave in accordance with the tasks that have been assigned to him."

Schwartz in Wibowo (2010: 9) "performance as a management style that is basically open communication between managers and employees regarding goal setting, feedback from managers to employees and vice versa from the employee to the manager."

"Performance is the result of work that can be achieved by a person or group of people within an organization or institution, in accordance with the authority and responsibilities of each, in an effort to achieve the goals of the organization in question legally, does not violate the law and in accordance with the moral ethics that have been determined ".

Wake up (2012: 230) "through the performance appraisal process can be known to result from organizational such, is reached or not achieving organizational goals."Hasibuan (2013: 193) states "discipline is a function of the operative management of human resources is important because the better discipline employees, the higher the performance it achieves. Without the discipline of good employees, it is difficult for the organization to achieve optimal results. "

From these explanations, it can be concluded that the performance of employees in an organization is strongly influenced by employee discipline. If among employees work discipline has been ignored, it is certain that the performance will decrease.

Based on the description in the above framework and to address the identification problem, the writer can formulate a hypothesis, "allegedly a significant difference between the discipline of work to employees performance at PT. Atri Distribution Pare-Pare ".

\section{A. Location and Time Research}

\section{Research Methods}

The author conducted research at PT. Atri Distribution Pare-Pare located in Pare-Pare. While the time is used for this study is for 2 (two) months from the beginning of October to the end of December 2014.

\section{B. Types and Sources of Data}

The types and sources of data used in this study are as follows: Types of data used are: Qualitative data, ie data obtained either in the form of verbal or written information, such as a general overview of institutions, the results of questionnaires, interviews and other data that support research. Quantitative data, ie data and the data obtained are presented in the form of numbers.

\section{Data source}

Source of data used in the research work discipline influence on employee performance, namely: Primary data, ie data obtained from the observation or direct observation and interview the employees of PT. Atri Area Pare-Pare. Secondary data is data obtained directly but from other sources such as books and literature. 


\section{Data Collection Methods}

The methods of collecting data in this study are used:

1. Research library (library research), the research done through the review of literature books that are relevant to the title and the problems examined.

2. The field research (field research), the research done by visits directly on the object of research. To put the data field, used the technique as follows:

Observation, namely that direct observation by the author of the archive or the written data are generated periodically. Or question and answer interview with the head of the company, the head of personnel and number of personnel associated with the writing of this thesis.

Documentation, ie documents drawn from agencies such as the organizational structure and job descriptions and responsibilities. The questionnaire which is collecting data by distributing questionnaires in order to obtain accurate data.

\section{E. Population and Sample}

1. Population The population in this study were all employees at PT. Atri Distribution Pare-Pare totaling 78 people

2. sampleThe samples used in this study is 30 samples at PT. Atri Distribution Pare-Pare.

\section{F. Methods of Data Analysis}

1. Descriptive Analysis

Descriptive analysis which gives an overview of the results of research in general on some items of questions that are elements of the conduct of labor discipline influence on employee performance is the result taken from the answers and differences in their perceptions of each source to one another.

The steps in conducting research analyzes the influence of labor discipline on the performance of employees at PT. Pare-Pare Atri Distribution is as follows:

Liker scale for each indicator / sub variables assessed by the respondents, are classified into four alternative answers using ordinal scale / Liker depicting the rank answers. Answer rank each indicator were given a score between 1 and 5 . Calculated the total score of each variable / sub variable $=$ total score of all scores indicator variable for all respondents.

Calculated score of each variable / sub variable $=$ the average of the total score. To describe respondents also used descriptive statistics such as frequency distribution in the form of a table.

For each variable consists of 10 dimensions (weight) with a 20 item questionnaire and the number of respondents 30 people, then obtained criteria:

Actual score: Answer all respondents (30) people on 20 questionnaires. Ideal score: the highest weights multiplied by the number of samples that $5 \times 30=150 \%$ Actual score: Actual Score ideal score is divided and multiplied by $100 \%$, and then converted the criteria in the table following scores: To answer the main problem and prove a hypothesis that has been stated previously, the authors use the following method:

2. Statistical Analysis

a. Simple linear regression analysis is an analysis tool scores to determine the effect of labor discipline on employee performance by using the following formula:

Where :

$$
Y=a+b x
$$

$\mathrm{Y}=$ Employee Performance

$\mathrm{a}=$ Constant

$\mathrm{b}=$ coefficient regression

$\mathrm{X}=$ Discipline work

To determine the value of $\mathrm{a}$ and $\mathrm{b}$ used as following formula:

$$
\mathrm{b}=\frac{n\left(\sum x y\right)-\left(\sum x\right) \cdot\left(\sum y\right)}{n\left(\sum x^{2}\right)-\left(\sum x\right)^{2}}
$$

or

$$
a=\frac{\sum y}{n}-\mathrm{b} \frac{\sum x}{n}
$$

$$
a=\bar{y}-b \bar{x}
$$


The regression coefficient (b) is the contribution of the magnitude of changes in the value of the independent variable $(\mathrm{X})$, the greater the value of the regression coefficients, the contribution changes are also getting bigger, and vice versa will be smaller. Contributions change the variable $\mathrm{X}$ is also determined by the regression coefficient is positive or negative.

b. Furthermore, to determine the relationship between labor discipline influence on employee performance, use the formula of correlation (r) with the formula:

$$
r=\frac{n\left(\sum x y\right)-\left(\sum x\right)\left(\sum y\right)}{\sqrt{n\left(\sum x^{2}\right) \cdot\left(\sum x\right)^{2}} \cdot \sqrt{n\left(\sum y^{2}\right)-\left(\sum y\right)^{2}}}
$$

Information:

$\mathrm{n}=$ sample

To measure the interval closeness of the relationship, the correlation measurement standard is used as follows:

Table 1. Guidelines for the interpretation of the correlation coefficient (r)

\begin{tabular}{|l|l|l|}
\hline No & Interval KoefisienKorelasi & Tingkat Hubungan \\
\hline 1 & $0,00-0,20$ & Sangatlemah \\
\hline 2 & $0,21-0,40$ & Lemah \\
\hline 3 & $0,41-0,60$ & Sedang \\
\hline 4 & $0,61-0,80$ & Kuat \\
\hline 5 & $0,81-1,00$ & Sangatkuat \\
\hline
\end{tabular}

Sugiyono (2012: 142)

c. Then proceed with the coefficient of determination $\left(\mathrm{R}^{2}\right)$ using the formula:

$$
K D=r^{2} \times 100 \%
$$

1) T-test was performed to test the hypothesis test steps as follows:

Through hypothesis testing, namely:

H_0: $\beta 0=0$ (no effect on the performance of employees work discipline)

H_ $\alpha: \beta 0 \neq 0$ (no influence on the performance of employees work discipline)

2) Determining significant at $\alpha$ level of $5 \%$ by determining the $t-$ table at a significant level $=5 \%$ by the formula:

df $=\mathrm{n}-\mathrm{k}$

where $\mathrm{n}=$ the total sample and $\mathrm{k}=$ the two variables, namely $\mathrm{X}$ and $\mathrm{Y}$.

3) Determining the value of t-count, with the following formula:

$$
\mathrm{t}_{\text {Sum }}={ }_{\mathrm{r}^{2}} \sqrt{\frac{n-2}{\left(1-t^{2}\right)}}
$$

4) Comparing between $\mathrm{t}$-sum with t-table then make a conclusion, that is, if t-sum greater than $\mathrm{t}$-table then, Ho, Ha is rejected and accepted, whereas if t-sum smaller than $T_{-}$(table) then, Hois accepted and Ha refused.

\section{A. Characteristics of respondents}

\section{Results And Discussion}

To answer the problem formulation and prove the hypothesis proposed in this study, the authors identify the influence of discipline on the performance of employees at PT. Atri Distribution Pare-Pare.

1. Gender

Table 2. Percentage of respondents by sex

\begin{tabular}{|l|l|l|}
\hline Gender & Frequencv $(\mathbf{n})$ & Percentage (\%) \\
\hline Woman & 19 & 63.33 \\
\hline Man & 11 & 36.67 \\
\hline Total & $\mathbf{3 0}$ & $\mathbf{1 0 0 . 0 0}$ \\
\hline
\end{tabular}

Source: data processing, 2014 
From the above table can be seen respondents is 30 people, of which 19 respondents $(63.33 \%)$ womenand 11 respondents $(36.67 \%)$ were male respondents.

2. Level of age

Table 3. Percentage of respondents by age level

\begin{tabular}{|l|l|l|}
\hline Age & Frequency (n) & Percentage (\%) \\
\hline $26-36$ & 10 & 33.33 \\
\hline $37-46$ & 10 & 33.33 \\
\hline $46<$ & 10 & 33.33 \\
\hline Total & $\mathbf{3 0}$ & $\mathbf{1 0 0 . 0 0}$ \\
\hline
\end{tabular}

Source: data processing, 2014

The above table shows that of the 30 respondents there were 10 respondents (33.33\%) were aged 27-36 years, 10 respondents (33.33\%) were aged 37-46 years and 10 respondents (33.33\%) aged 46 <years.

3. Education

Table 4.Percentage of respondents by education level

\begin{tabular}{|l|l|l|}
\hline Education & Frequency (n) & Percentage (\%) \\
\hline Doctor & - & - \\
\hline Strata TwoS2) & 8 & 26.67 \\
\hline Strata One (S1) & 22 & 73.33 \\
\hline Total & $\mathbf{3 0}$ & $\mathbf{1 0 0 . 0 0}$ \\
\hline
\end{tabular}

Source: data processing, 2014.

PT. Atri Distribution Pare-Pare in 2014 was dominated by the employee level undergraduate education, where there are eight respondents (26.67\%) at a rate of two strata (S2), and 22 respondents (73.33\%) at the level of degree (S1), bringing the total level of education at the office of PT. Atri Distribution Pare-Pare by 30 respondents. This shows that employees are more dominant Undergraduate Degree (S1) in the office of PT. Atri Distribution Pare-Pare using skilled personnel with the ability of education is above average.

\section{B. Analysis of Employee Discipline}

In connection with the implementation of employee discipline (PNS) at PT. Atri Distribution Pare-Pare as one of the variables in this study, the results of questionnaires from 30 respondents obtained based on the respondents' statements on each of the statements in each variable. Actual score for the variable implementation of employee discipline is accumulation of the actual score of the 10 questions listed above, i.e. by 1226 . While the ideal score to 1 variable obtained an ideal score of each item 150 x questions in these variables: $150 \times 10=$ 1500. Now we know the actual score and the ideal score, and then performed the calculations to determine the percentage of the actual score, as follows:

Percentage $(\%)$ Actual Score $=\frac{\text { Skoraktual }}{\text { Skorideal }} \times 100$

$=\frac{1226}{1500} \times 100$

$=81.73 \%$

\section{Analysis of Employee Performance}

Employee performance as one of the variables into a level to be considered in this study, the analysis of respondents from 30 respondents. Actual score for the variable implementation of employee performance (PNS) is the accumulation of the actual score of the 10 questions listed above, ie by 1242 . While the ideal score to 1 variables obtained from skorideal each item $150 \mathrm{x}$ number of questions in the variable 10: $150 \mathrm{x} 10=1500$. Now we know the actual score and the ideal score, then performed perhitingan to know the percentage of the actual score, as follows:

$=\frac{1242}{1500} \times 100$

Percentage $(\%)$ Actual Score $=\frac{\text { Skoraktual }}{\text { Skorideal }} \times 100$

$=82.8 \%$

\section{Relationship betweenDiscipline to Performance}

To determine the effect or linkage between the discipline of work to employees performance of PT. AtriDistribution Pare-Pare, the authors use statistical methods as follows:

1. Simple Linear Regression

To get a simple linear regression equation then in the calculation must be determined beforehand components as well as the constants $a$ and $b$, with a population and a sample of 30 employees. 
To get the value of $a$ and $b$, then the calculation above is substituted into the equation $a$ and $b$ :

$\mathrm{b}=\frac{\mathrm{n}\left(\sum \mathrm{xy}\right)-\left(\sum \mathrm{x}\right)\left(\sum \mathrm{y}\right)}{\mathrm{n}\left(\sum \mathrm{x}^{2}\right)-\left(\sum \mathrm{x}\right)^{2}}$

$\mathrm{b}=\frac{30(647.71)-(159.5)(124.3)}{30(2171.73)-(159.5)^{2}}$

$\mathrm{b}=0.61$

To value a:

$\mathrm{a}=\frac{\left(\sum \mathrm{y}\right)}{\mathrm{n}}-\mathrm{b} \frac{\left(\sum \mathrm{x}\right)}{\mathrm{n}}$

$\mathrm{a}=\frac{(124.3)}{30}-0.61 \frac{(159.5)}{30}$

$\mathrm{a}=2.10$

We get the simple linear regression equation as follows:

$$
\mathrm{Y}=2.10+0.61 \mathrm{X}
$$

a. Intercept or constants $2: 10$

Without the application of the discipline of work, then the employee's performance reaches. 2:10.

b. directions relationship From Equation visible sign "+" describes the positive relationship or the direction, this means that the level of discipline will improve performanceemployees.

c. The regression coefficient 0.61

Relations with the discipline of performance is, if the employee disciplineby 1 point then the performance will increase as well be 0.61

\section{Correlation Coefficient (r)}

In addition to using simple linear regression, the relationship between Discipline performance can be determined by using the formula ( $r$ ), the difference between a simple linear regression with a correlation coefficient (r), is the goal. Simple linear regression aims to determine the relationship between variables in general, while the correlation coefficient (r), which aims to determine how the relationship between the two variables.

And then to find out the relationship between the discipline of the employee's performance, then the components above is substituted into the correlation (r). and the calculation of the correlation coefficient appears as follows:

$$
\begin{aligned}
& \mathrm{r}=\frac{30(647.71)-(159.5)(124.3)}{\sqrt{30(2171.3)-(159.5)^{2}} \sqrt{30(519.8)-(124.3)^{2}}} \\
& \quad \mathrm{r}=0,6025
\end{aligned}
$$

From the results of calculations for coefficients (r) above, it can be argued that the discipline with the performance of employees of PT. Atri Distribution Pare-Pare had a positive effect with a high level of relationship. So from this calculation also can be used as a reference for improving the discipline and performance, especially in the scope of PT. Atri Distribution Pare-Pare.

\section{Coefficient of Determination}

To determine the level of discipline affecting the performance, then this can be determined by using the calculation formula coefficient of determination. The magnitude of the coefficient of determination is quadrat of the correlation coefficient and formulated as follows:

$r^{2}=\mathrm{r} \times \mathrm{r}$

$\mathrm{r}^{2}=0,6025 \times 0,6025$

$r^{2}=0,3630$

the calculation of the coefficient of determination ( $\left(\begin{array}{r}2 \\ \text { ) }\end{array}\right.$ is 0.3630 , this indicates that the level of discipline may affect the performance that employees at PT. Atri Distribution Pare-Pare by $36.30 \%$, with the remaining $63.70 \%$ influenced by other variables.

\section{Hypothesis Tester (t-test)}

To prove the above hypothesis which says that the work discipline allegedly significant effect on the performance of the employee (PNS) at PT. Atri Distribution Pare-Pare, then when used a hypothesis testing via 
t-test. This test is used to test whether or not a significant relationship between work discipline with the performance of employees at the Office of PT. Atri Distribution Pare-Pare.

t-count values obtained as follows:

$$
\begin{aligned}
& t=0,6025 \sqrt{\frac{(30-2)}{(1-0,3630)}} \\
& t=0,6025 \sqrt{\frac{28}{0.637}} \\
& t=3.9
\end{aligned}
$$

Where before $t$ test was conducted to first determine degrees of freedom or the degree of freedom (df). In determining the degrees of freedom (df) on hypothesis testing is done by the formula:

$\mathrm{df}=\mathrm{n}-\mathrm{k}$

Where :

$\mathrm{n}=$ Number of respondents

$\mathrm{k}=$ number of variables

From the equation above obtained value of degrees of freedom ( $\mathrm{df}$ ) as follows: $\mathrm{df}=30-2$

$\mathrm{df}=28$

For value of $\mathrm{df}=28$, a significance level $\alpha=5 \%$ and a hypothetical two-way got $\mathrm{t}_{\text {Count }}$ of the table statistics (T table) amounted to 1,785. Bybecause $t_{\text {count }}>t_{\text {table }}(3.9>1.785)$ at $5 \%$ level, then $\mathrm{H}_{\mathrm{o}}$ is rejected and $\mathrm{H}_{\mathrm{a}}$ accepted, this means thevalue of $\mathrm{Y}$ (performance) depends on the value of $\mathrm{X}$ (discipline) employee.

So the conclusions that can be drawn from the above hypothesis test step is work discipline significantly influence employee performance improvement therefore the hypothesis is accepted. Thus the results of the study to test the hypothesis above the reception area and rejection Ha Ho shown in the following figure:

Figure 4. Regional Acceptance Ha

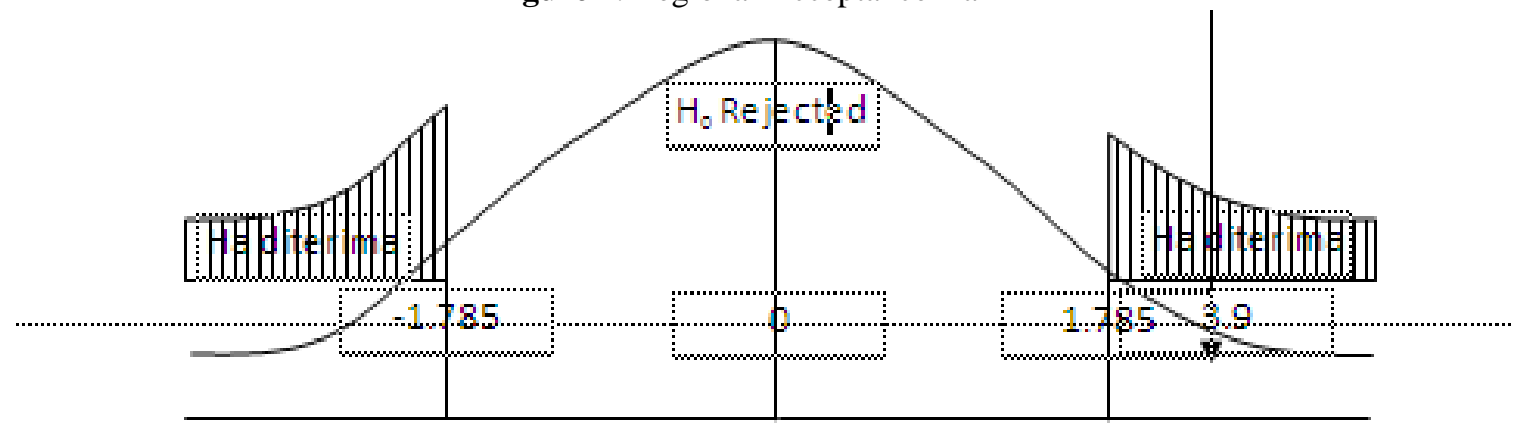

The results of this study are consistent with the theory Hasibuan (2013: 193) states that "discipline is the operative functions of human resource management is important because the better discipline of employees, the higher the performance it achieves. Without the discipline of good employees, it is difficult for the organization to achieve optimal results. "This is in line with the

\section{A. Conclusion}

\section{Conclusion}

on the results of the analysis of each variable, by making a comparison between the actual score and the ideal score is concluded that:

Discipline employee reached $81.73 \%$ or included excellent. Similarly, the performance of employees at PT. Atri Distribution Pare-Pare reached $82.8 \%$ and is at a good rating.

Analysis of statistical studies have shown that the discipline with the performance of employees have a level of relationship is (concrete) on the coefficient of determination $\mathrm{r} 2=0.3630$, which means that the discipline capable of affecting the performance of $36.30 \%$ and the remaining $63.70 \%$ influenced by other variables.

Results of hypothesis testing t-test showed that $t_{C o u n t}>t_{T a b l e}(3.9>1,785)$. This shows that the disciplinary significant effect on the performance of employees at PT. Atri Distribution Pare-Pare, so the higher discipline the employee, then the performance will be better. Thus the hypothesis proposed by the author accepted. 


\section{B. Suggestions}

In connection with the previous conclusion, it can be submitted suggestions:

Discipline is something that is closely related to good performance in the organization or institution, private or government because without the discipline of the employee or employees the maximum performance will be difficult to achieve. Therefore, to get the maximum performance from all employees at PT. Atri Distribution Pare-Pare then discipline should get serious attention yamg. And in the research discipline of employees at PT. Atri Distribution Pare-Pare is at a very good title, it is expected that all employees at PT. Atri Distribution Pare-Pare in order to defend this title. In this study, the performance is at a good rating, and therefore is expected to employees at PT. Atri Distribution Pare-Pare in order to improve this predicate to continue to uphold discipline in performing their duties.

\section{Bibliography}

[1]. Bangun, Wilson. 2012. Manajemen Sumber Daya Manusia, Bandung: Erlangga.

[2]. Dessler, Gary, 2003. Manajemen Sumber Daya Manusia, Edisi 10 Jilid 11. Jakarta : PT. Indeks.

[3]. Hasibuan, M.S.P. 2002. Kekaryawanan Indonesia, Mas Agung, Jakarta

[4]. , 2013. Manajemen Sumber Daya Manusia Edisi Revisi, Jakarta: Bumi Aksara.

[5]. Marwan Syah, Sjafri. 2010. Bisnis, Manajemen, dan Sumber Daya Manusia IPB Press, Bogor

[6]. Rivai, Veitzal. 2011. Manajemen Sumber Daya Manusia untuk Perusahaan. Rajawali Pers. Jakarta.

[7]. Ravianto, J. 2009. Produktivitas dan Manusia Indonesia. Jakarta: Lembaga SIUP.

[8]. Mondy, R. Wayne. 2008. Manajemen Sumber Daya Manusia, Edisi Kesepuluh, Jakarta : Erlangga.

[9]. Muhsin, A. (2016). The Effectiveness of Positive Feedback in Teaching Speaking Skill. Lingua Cultura, 10(1), 25-30.I

[10]. Muhsin, M. A., \& Sastrawati, i. Ketergabungan pendidikan karakter dan positive feedback dalam pembelajaran bahasa inggris. Researchgate. Unpublish Paper.

[11]. Sutristo, Edy. 2009. Manajemen Sumber Daya Manusia. Kencana, Jakarta.

[12]. Sugiono, 2012. Metode Penelitian Kombinasi, Alfabeta, Bandung.

[13]. Tika, Prabundu. 2010. Budaya Organisasi dan Peningkatan Kinerja Perusahaan, Jakarta.

[14]. Wibowo, 2010. Manajemen Kinerja, Jakarta: Raja Grafindo Perkasa.

[15]. Mangkuranegara, AAA. 2004. Perencanaan dan Pengembangan Sumber Daya Manusia Bandung: Reflika Aditama

[16]. Sinambela, Lijan Poltak. 2012. Kinerja Karyawan, Teori Pengukuran dan Implikasi. Yogyakarta : Graha Ilmu.

[17]. Sutrisno, Edy. 2010. Manajemen Sumber Daya Manusia. Jakarta: Kencana. 